Article

\title{
Emotions and Political Narratives: Populism, Trump and Trade
}

\author{
Amy Skonieczny \\ Department of International Relations, San Francisco State University, San Francisco, 94132, USA; E-Mail: askonie@sfsu.edu
}

Submitted: 11 May 2018 | Accepted: 21 August 2018 | Published: 28 December 2018

\begin{abstract}
In 2016, a wave of American populism triggered emotional reactions to issues like trade and immigration, and dramatically impacted the Obama administration's plans to ratify the Trans-Pacific Partnership (TPP) during President Obama's final year in office. This article asks how do emotions infuse populism with political power, and why was populism effective in sparking American economic nationalism and retreat from free trade during the 2016 presidential campaign? Drawing on a psychoanalytic, narrative framework, the article argues that populist narratives deployed by US presidential candidates Donald Trump and Bernie Sanders characterized the American economy as a story of the people versus corrupt elites offering greater audience resonance that ultimately derailed President Obama's plan to pass the TPP and ushered in an era of economic nationalism under President Trump. The article contributes to the literature on emotions and foreign policy and explores the under-studied emotional features of populism as a discursive narrative.
\end{abstract}

\section{Keywords}

economic nationalism; emotions; identity; narratives; populism; trade; Trans-Pacific Partnership; Trump; US foreign policy

\section{Issue}

This article is part of the issue "Interdisciplinary Approaches to Studying Emotions within Politics and International Relations", edited by Alex Prior (University of Leeds, UK) and Yuri van Hoef (Utrecht University, The Netherlands).

(C) 2018 by the author; licensee Cogitatio (Lisbon, Portugal). This article is licensed under a Creative Commons Attribution 4.0 International License (CC BY).

\section{Introduction}

In 2016, the turn against free trade led by US Presidential candidates Bernie Sanders and Donald Trump came as a surprise to many US policymakers set on passing the Trans-Pacific Partnership (TPP) during the last year of President Obama's presidency. Throughout 2015-2016 presidential campaign, the candidates effectively used economic populist rhetoric to turn the TPP and past trade agreements into equivalences with economic disaster and bad political decisions. The eventual collapse of US efforts to pass the TPP left many wondering why the anti-trade, economic populism of candidates resonated with so many Americans. Why was economic populism so appealing to so many across the left-right political spectrum?

This article argues that populism contains a core story about 'the people' reclaiming power from 'elites', and when applied to policy issues such as the TPP and trade, can turn dry, abstract economic issues into compelling narratives of betrayal, corruption, oppression and loss. Populist narratives overcame a pro-trade, pro- globalization, pro-TPP campaign by invoking powerful, charged characterizations of who 'we' are, who is to blame, and what the future should be, all framed in emotional language. In examining the public messaging on trade and the economy, the article finds that the economic populist campaigns of presidential candidates Bernie Sanders and Donald Trump more effectively evoked feelings of a certain type of 'we-ness' and connected better with the audience by conveying an emotional expression of lack and desire for repair of something broken that sparked wide-spread resonance with many Americans, ultimately derailing President Obama's plans to ratify the TPP.

Drawing insights from Ty Solomon's (2013) work on the resonances of neo-conservatism, the article develops a psycho-analytic, narrative framework that draws on Lacan (1981), and applies it to selected speeches on the economy and trade from the Obama administration and presidential candidates Bernie Sanders and Donald Trump during the 2015-2016 presidential campaign. UItimately, the driving emotional features of resonate discourses, lack and desire as articulated by Solomon's work, 
as well as fantasy and transgression (Eberle, 2017), are conceived here as emotional elements of story showcasing the benefits of bridging a Lacanian framework with narrative analysis and applying it to economic populism.

\section{Emotions, Populism and Political Narratives}

The study of emotions and affects as critical elements of discourse and language are flourishing in the International Relations literature (see, for example, the recent forum on emotions and discourse by Koschut, 2017b; see also Bially-Mattern, 2011, 2014; Bleiker \& Hutchison, 2014;Clément \& Sanger, 2018; Crawford, 2000; Eberle, 2017, 2018; Fierke, 2013; Hall, 2015; Koschut, 2017a; Solomon, 2014; Steele, 2010). More recently, scholars of populism have also argued that the emotional appeals of populist discourse provoke audience associations and mobilizations (Rico, Guinjoan, \& Anduiza, 2017; Salmela \& von Scheve, 2017). By turning to the study of emotions and affect, scholars contend that resonance can be better understood. In the past, scholars have sometimes struggled to explain why one discourse is more dominant than another or why one narrative wins out over another in a narrative clash (Solomon, 2013).

Ty Solomon (2013) argues that an explanation for why some discourses are more appealing than others is that some discursive constructions are infused with feelings such as anxiety, fear, desire or hope that provoke audience identification or relatability. Salmela and von Scheve (2017) found that emotions and feelings were central in right-wing populist rhetoric and that policy issues were framed in terms of emotions such as fear, anxiety, anger and feelings of powerlessness. Minkenberg (2000) claims that an underlying emotional content of the radical right channels a sensibility of 'modernization losers' where right-wing populism reflects a feeling of shrinking social and cultural capital rather than pure victimhood. In this sense, Salmela and von Scheve (2017) argue that the repressed shame of loss of social, economic and cultural stature seeks to be directed away from the self onto others as hatred and anger at other groups. Elaborating on this point, Jakob Eberle (2017) discusses what Lacan describes as transgression. It is an aspect of a particular type of story-a fantasy-wherein something or someone prevents the subject from obtaining wholeness and certainty, and not only exacerbates feelings of anxiety but actually enjoys the process of taking something away. As Eberle (2017) explains, the fantasy story fuels fervor by emphasizing the transgression "in which someone is depicted as stealing our enjoyment by blocking our achievement of a whole identity-and as enjoying herself in doing so" (p. 13). As such, a discourse of populism resonates because it directs feelings of lack and shame towards blame of others-typically elites but also scapegoats such as immigrants, refugees and economically weak groups like the long-term unemployed-and depicts them as taking advantage of others, the system or "the mark" (Glynos, Klimecki, \& Willmott, 2012) and enjoying it.
In addition to analyzing how emotions affect discursive resonance, some scholars of emotions show that it is not just what is said, but how it is said that evokes audience association and strengthens identification with the speaker's position. For example, Steele conceptualizes discursive power as a strata made up of psychological, imaginative and rhythmic layers (2010). Rhythm helps explain the how of power-how it is articulated in iterative forms (Oren \& Solomon, 2015), in operationalized practices (Steele, 2010), and in repetition (Oren \& Solomon, 2015). Particularly in political speeches designed to illicit audience emotions either in support or opposition to an issue, iteration and repetition of certain, often ambiguous phrases, draws the audience into the performance as producers of the political spectacle (Edelman, 1988) that is the campaign rally, the 'stump speech', the 'roll-out' or the 'launch' of a campaign. In Oren and Solomon's (2015) work, they argue that audience engagement in political speech in terms of chants, and call and response repetition of simple phrases, such as Weapons of Mass Destruction (WMD), is productive of a speech act and an ignored element of 'illocutionary force'. Indeed, Donald Trump's campaign rallies always include an audience call and response element such as the phrase 'lock her up' whenever he mentioned his political opponent. On June 27, 2018 the Daily Show even made fun of this particular style by tweeting the following after Donald Trump's rally in Minnesota: “Move over 'lock her up.' There's a new chant sweeping through MAGA (Make America Great Again) country: "SPACE FORCE!" (The Daily Show, 2018). During the Democratic National Convention in 2016, Bernie Sanders supporters chanted "No TPP" so loudly that several scheduled speakers, including President Obama, had to stop and attempt to quiet them (Arnold, 2016). To sum up, how the speech is delivered, including the way the audience engages or even disrupts, creates a speech experience that elevates emotion and audience resonance for or against an issue.

In his 2013 article, Solomon developed a framework built on Jacques Lacan (1981) to explain why the discourse of neoconservatism resonated with audiences and successfully drove the Bush administration's foreign policy in the 2000s as opposed to the 1990s when the ideas first circulated after the end of the Cold War. He found that an effective discourse must spark desire, and give voice to the subjects feeling of lack. Solomon's framework can provide insight into how the emotions of populism can mobilize audiences and succeed in rallying audiences against free trade.

Drawing on Lacan, Solomon (2013) conceptualizes the subject as decentered and longing for a stable sense of self. This perpetual but always unsatisfied desire for wholeness produces affect as subjects long to be made whole even if it is an unobtainable goal. As Solomon states, "The subject is constituted around a lack; an always missing 'full' sense of self that the subject always pursues through identification practices yet never ultimately attains" (2013, p. 105). Subject identifications 
come, in part, from societal signifiers of national identity such as 'democracy', 'freedom', 'rights' or other types of collective identities proscribed in a discourse. Individuals see themselves as part of a collective whole and seek identifications with symbols of this collective.

This approach helps explain why individuals relate to seemingly abstract discourses such as neoconservatism and populism. Both discourses are ripe with symbols that fulfill, at least partly, a subject's desire for identification. It is this desire (for wholeness) that is the driving force that connects subjects with identifications as they seek meaning and enjoyment in pursuing fantasies that they will someday be whole again and fulfilled. However, the closer the subject feels to the object associated with wholeness, the quicker desire fades. For Lacan (1981), it is the fantasy of wholeness and the desire stimulated by lack that offers a stabilizing discursive identity for the subject. Thus, Solomon (2013) argues that the more a discourse represents lack as the political state of affairs, the more fantasies result creating greater identification for subjects. Moreover, Eberle (2017) contends that as a sense of lack drives desire for wholeness, it leads to a "fantasy narrative" that envisions how that wholeness might come about in the future or, in contrast, a "disaster scenario" that might prevent wholeness from coming to fruition (p. 6).

While Solomon (2013) refers to neoconservatism as a discourse, his framework could be interpreted as a narrative-a crafted and imbued story that has subjects, objects, past and future-a sense of time that gives it a plot. As Eberle (2017) points out, although starting from different perspectives, there is an enriching "trading zone" between Lacanian and narrative approaches that benefits both (p. 6). Patricia Ewick and Susan Silbey (1995) identify three elements of narrative construction: 1) a selective recounting of past events and characters, 2) the events described are temporally ordered, 3) the events and characters are related to one another and embedded in some overarching theme that makes up the overall feeling or impression of the story (p. 200). Miskimmon et al. (2013) put it this way: "A narrative entails an initial situation or order, a problem that disrupts that order, and a resolution that reestablishes order.....Narrative therefore is distinguished by a particular structure through which sense is achieved" (p. 5). In this way, populism can also be looked at as a narrative where the core ideas of it are used in story-form to connect a subject (the people versus the elite) theme to a problem (free trade that destroys the middle class) and a resolution (protectionism).

However, while narrative approaches explain how certain policies are linked to themes or ideas, and to particular subjects, they present narratives as constructing a sequential order that helps make sense. In so doing, the underlying affective drivers that give certain narratives force are overlooked and it can be hard to understand why some narratives are so powerful even when the content is ordered much the same way as other narratives.
In connecting narrative approaches with psycho-analytic approaches to emotions, Lacan's concepts of desire, lack and fantasy help show what drives attachment and identification with certain narratives over others. From a Lacanian point of view, narratives feed our fundamental desire to cover a lack, overcome anxiety, and our "hunger for certainty" (Edkins, 2000, p. 154) and achieve a complete and stable identity even though this is, in fact, impossible, making it a fantasy rather than anything actually obtainable. Eberle (2017) states that in addition to the emotions derived from the drive to overcome lack and push towards wholeness, fantasy narratives "are distinguished from other narratives by their excessively simplified and clear-cut, 'black and white' character, which leaves little room for ambiguity or uncertainty...in fantasies, there are only two possible versions of the future with no middle ground: either we recapture the 'object' and we are safe (the beatific scenario of securing a complete identity), or we fail and we are doomed (the horrific scenario of losing it)" (pp. 6-7). Thus, it's not just selective events and characters ordered in a particular sequence that makes a compelling story-it's also the emotion in it that does.

Combining Solomon's Lacanian framework with a narrative approach produces a method for analyzing texts, such as campaign speeches. Increasingly, scholars have called for more transparent methodological approaches to the study of emotions (Clément \& Sanger, 2018). In line with this thinking, this article develops a methodological framework from Solomon's (2013) work that articulates his theoretical insights through a narrative structure. Interpreting Solomon's (2013) work as narrative elements produces the following framework: collective subjects/actors, the theme or characterization of the socio-political environment in terms of lack or wholeness, and how the past and the future are fantasized. This framework is diagramed in Figure 1.

In applying this framework to the example of trade and the TPP during the 2016 campaign, I am able to analyze the different emotional resonances of the Obama administration's 'trade' narrative compared to the candidates' trade narratives, and better explain why populism had the impact it did on the TPP debate in the US.

In the sections below, I apply the Lacanian-narrative framework to speeches from President Obama, Bernie Sanders and Donald Trump. The 2015-2016 period produced hundreds of press releases, media coverage, campaign ads and speeches on the TPP, and I selected the defining speeches on trade, the economy and TPP as representative of the overall trade/TPP narrative of each speaker. Since I was interested in understanding how and why Trump and Sander's emotional anti-TPP messaging derailed President Obama's pro-TPP campaign, I focused on only those three speakers. While it is the case that presidential candidate Hillary Clinton also eventually shifted her position against the TPP, she was not representative of a populist, economic nationalist candidate and so I did not include her in this analysis. My analysis 


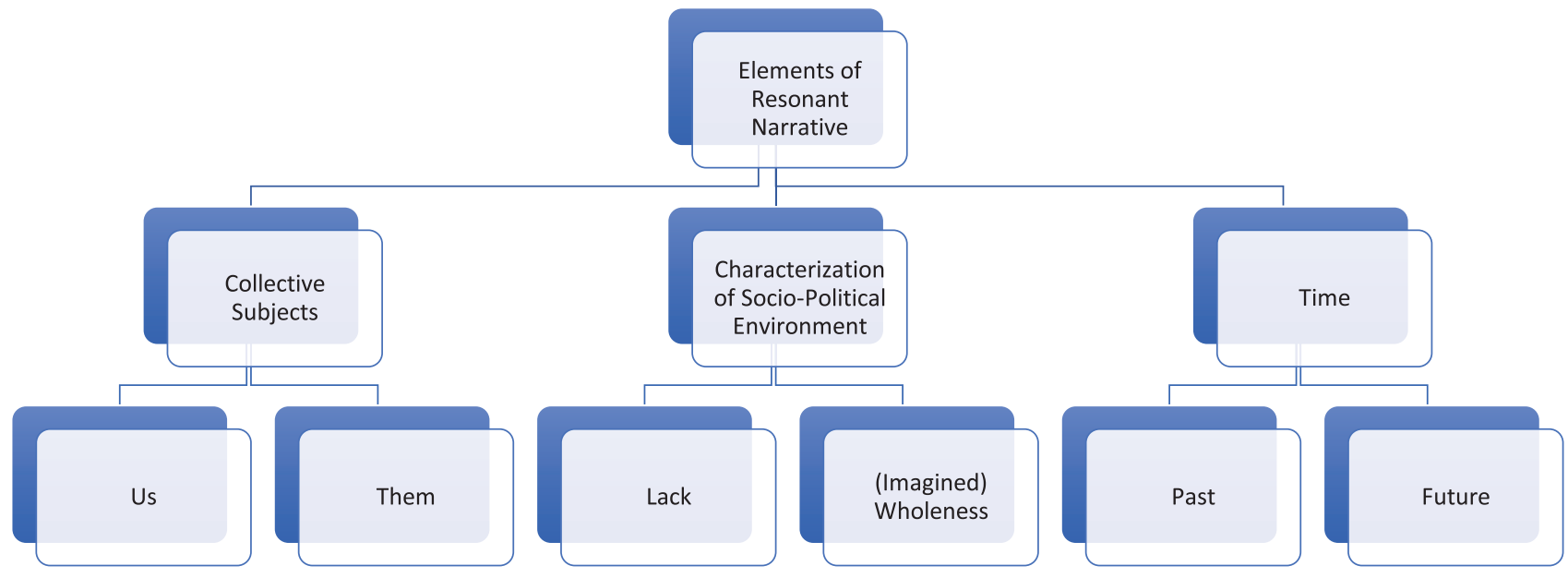

Figure 1. Lacanian-narrative framework.

shows that the candidates' narratives presented more attractive 'objects', more effectively aroused desire in audiences and offered retribution for transgressions of elites, ultimately creating stronger audience identification and resonance with their populist trade stories.

\section{The Trans-Pacific Partnership: Economic Opportunity or Economic Disaster}

In 2015, the US domestic climate for trade policy looked a lot like past free trade domestic battles, and President Obama signaled a robust public outside-lobbying campaign to convince the public and thus the Congress to ratify TPP during his final year in office. He relied on typical free-trade narratives that had been successful in the past (Skonieczny, 2001, 2018) and presented the TPP as a pro-globalization opportunity for American workers, a regional balance against a threatening China and an inevitable progression of the globalized economy that would lead to a prosperous future.

However, 2016 proved to be an unusual year for US election politics. During the 2016 presidential primary season, Republican candidate Donald Trump and Democratic candidate Bernie Sanders (and eventually Democratic nominee Hillary Clinton) aligned against the TPP offering a powerful, populist anti-trade message that resonated with an American public concerned with job loss and American decline. The anti-trade counter-narrative of Sanders and Trump constructed a story about free trade as a series of economic disasters that put Americans out of work, displaced the middle-class and benefitted rich elites and pro-business corporations, and this rallied NGOs, labor unions and others opposed to trade policies.

\subsection{President Obama: Trade as Hope; TPP as a Balance against China}

This section analyzes President Obama's pro-TPP narrative through the Lacanian-narrative framework discussed above. In particular, it focuses on one main speech given by President Obama on May 8, 2015, at the Nike headquarters in Beaverton, Oregon shortly after Bernie Sanders and Hillary Clinton had announced their candidacies for president but before Donald Trump's announcement. The speech, titled "Remarks on Trade", took place just prior to the 'fast-track' authority vote in Congress and was no doubt aimed at shoring up support for his trade legislation agenda which primarily included the TPP.

In it, Obama constructs a specific collective subject, the small business owner or entrepreneur, he characterizes the socio-political environment more towards wholeness over lack, and emphasizes a hopeful and optimistic American (fantasized) future (see Figure 2).

There are several striking features of the speech that showcase the overall pro-TPP messaging produced by the White House. The speech took place at Nike Headquarters - this choice of location and backdrop as well as choice of audience (Nike workers) projected a certain aesthetic power (Steele, 2010) and resonance that favored the primary subjects of Obama's speechentrepreneurs and small businesses-and the unstated subject-corporations-arguably the subjects with the most to gain from the TPP free trade agreement. The choice of backdrop displays confidence in a 'winning' trade message that combined pro-globalization arguments with an anti-China, us/them character clash indicative of past trade victories (Skonieczny, 2018). It combines well with Obama's characterization of the sociopolitical environment as full of opportunity (rather than lack) and his optimistic, hopeful fantasy of the future as one where American entrepreneurs innovate, lead through technological development and set the standards for the rest of the world. Because the speech took place before the candidates' Sanders and Trump really began their campaigns in earnest, Obama's TPP narrative stands out as one not yet exposed to the populist surge that was just around the corner. However, even a full year later, Obama continued to push his TPP narrative primarily to business groups even as (or per- 


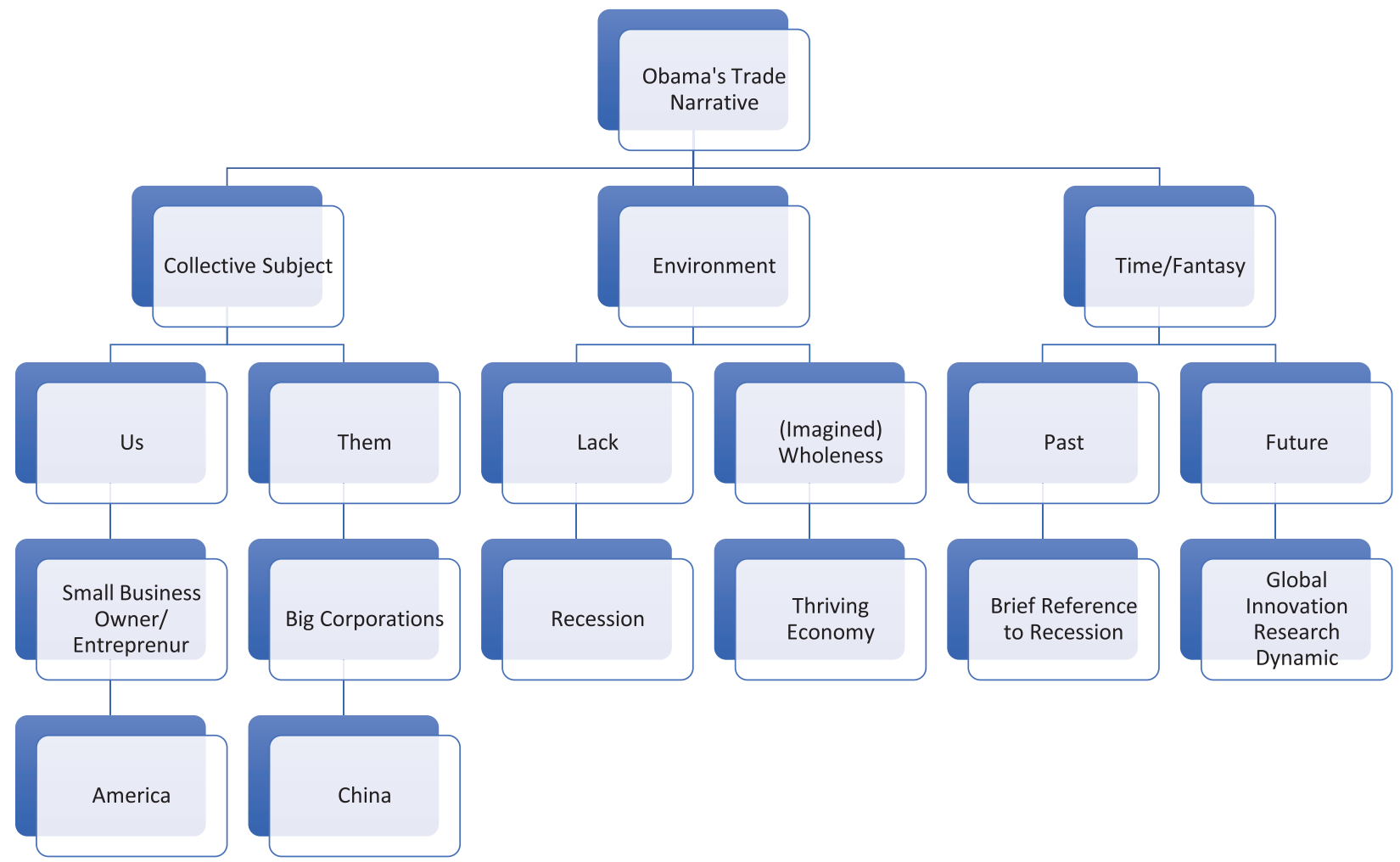

Figure 2. Obama's trade narrative.

haps because) he encountered increased resistance at home as the presidential election heated up and antiTPP sentiment grew. For example, in June 2016, President Obama continued his push for TPP to business audiences gathered by a federally-sponsored business group, SelectUSA: "This is not just about jobs and trade, it's not just about hard cold cash. It's also about building relationships across borders. When your companies come together, you help bring countries and cultures together" (Miller, 2016). Again, the main characters in Obama's TPP narrative continued to be businesses, building elite relationships with other businesses in foreign cultures. This particular type of 'trade story' unintentionally fueled an opposition built on populist sentiment that characterized the middle class environment as one filled with lack and exploitation from corporate elites who benefitted at their expense.

\subsection{The Candidates' TPP Narrative: Populism, Despair, Transgression and a Scapegoat}

In contrast to President Obama, Trump and Sanders trade narratives focused primarily on the exploitative relationship between subjects in a populist story of corrupt/corporate elites vs. the everyday people/worker. The power of the populism storyline in their anti-trade narrative came, in part, from tactical use of emotional language that emphasized a lack created by workers being 'left behind' by globalization and by 'others' taking something away whether China, Mexico, corporations, 'the elite' or immigrants. For example, at a speech at a United Steelworkers rally in Indiana, Sanders stated:

We must rewrite our disastrous trade policies that enable corporate America to shut down plants in this country and move to Mexico and other low-wage countries. We need to end the race to the bottom and enact trade policies that demand that American corporations create jobs here and not abroad. (Sanders, 2016)

In this segment, Sanders signals that 'corporate America' is the responsible party who 'prevents wholeness' and causes a painful lack of progress for the working class suggesting a corporate 'transgression' profiting off of this action at the expense of the 'little guy'. As Eberle (2017) suggests certain narratives provide more attractive 'objects' of desire (e.g.: factory jobs) promised by fantasy futures that present the situation in notably 'black and white' terms (disastrous trade agreements caused by past actions of politicians corrupted by corporate elites) as fixable by future courses of action (Sanders' and Trump's economic plans of retreating from free trade and bringing jobs back). Moreover, Sanders and Trump enact collective identities that were favorable to a wider margin of American society such as the 'working people' or 'middle class'. In fact, in 2017, 62\% of Americans self-identified as middle class (Newport, 2017).

In a similar narrative construction, one month earlier, Trump wrote an Op/Ed in USA Today against the TPP. 
He wrote:

The great American middle class is disappearing. One of the factors driving this economic devastation is America's disastrous trade policies....America's politicians-beholden to global corporate interests who profit from offshoring-have enabled jobs theft in every imaginable way. They have tolerated foreign trade cheating while enacting trade deals that encourage companies to shift production overseas. (Trump, 2016a)

Like Sanders, Trump emphasizes a corporate transgression that looked the other way while foreign countries (unspoken China) stole (wholeness) from the working people in America. The orientation of the candidates' narratives towards lack (stolen wholeness), corporate transgression and exploitation, and thus a fantasy future of change towards a new approach to trade, or repeated disasters if the candidates' vision is rejected, is almost diametrically opposed to Obama's trade story and thus, made the choice abundantly black and white.

In Figures 3 and 4 below, Sanders' campaign announcement speech in Burlington, Vermont, on May 26, 2015, and Donald Trump's speech on trade in Monessen, Pennsylvania, on June 28, 2016, are diagramed to show how the Lacanian-narrative framework applies to the two speeches.

As diagrammed in Figure 3, Sanders' announcement speech emphasizes a collective subject, the American people and workers, who have been shut out of politics and exposed to the greatest wealth inequality of America's history. Sanders' presents a socio-political environment gone very wrong and in need of a people's revolution to get America back on track. He suggests a scapegoat (lobbyists and super PACs) and contrasts his collec- tive subject with the billionaires who benefit most from the current system (and are pretty happy about it), which just further exacerbates the transgression and thus, audience desire for an object that rights the wrongs.

In Figure 4, Trump's speech is diagrammed. It shows the many similarities to Sanders' in terms of how they construct a common collective subject, position opposites and characterize the current socio-political environment. Trump's speech is specifically about trade and the economy and directly addresses the TPP. It similarly sets up a common, populist storyline of workers versus powerful corporations and financial elites. It also characterizes the current socio-political environment as one of extreme lack deliberately caused by politicians and their bad trade deals. He harkens back to a past where the economy thrived due to a robust industrial, producerist economy and calls for an 'America first' future that only he can ultimately create. Of all the speeches, Trump's stands out for his prolific use of emotional trigger words and extreme characterizations.

The next sections break-down the narrative segments (characters/subjects, theme/characterization of the environment, and fantasies of the past/future) to further compare the different ways Obama and the candidates construct their TPP/Trade narratives.

\section{Elements of Opposing Trade Narratives}

\subsection{Collective Subjects}

In contrast to the candidates' narratives where the 'worker' is the collective subject, Obama bases his collective subject on the small business owner and the entrepreneur. He contrasts small business owners with the big corporations typically associated with benefitting from free trade agreements. For example, he states early

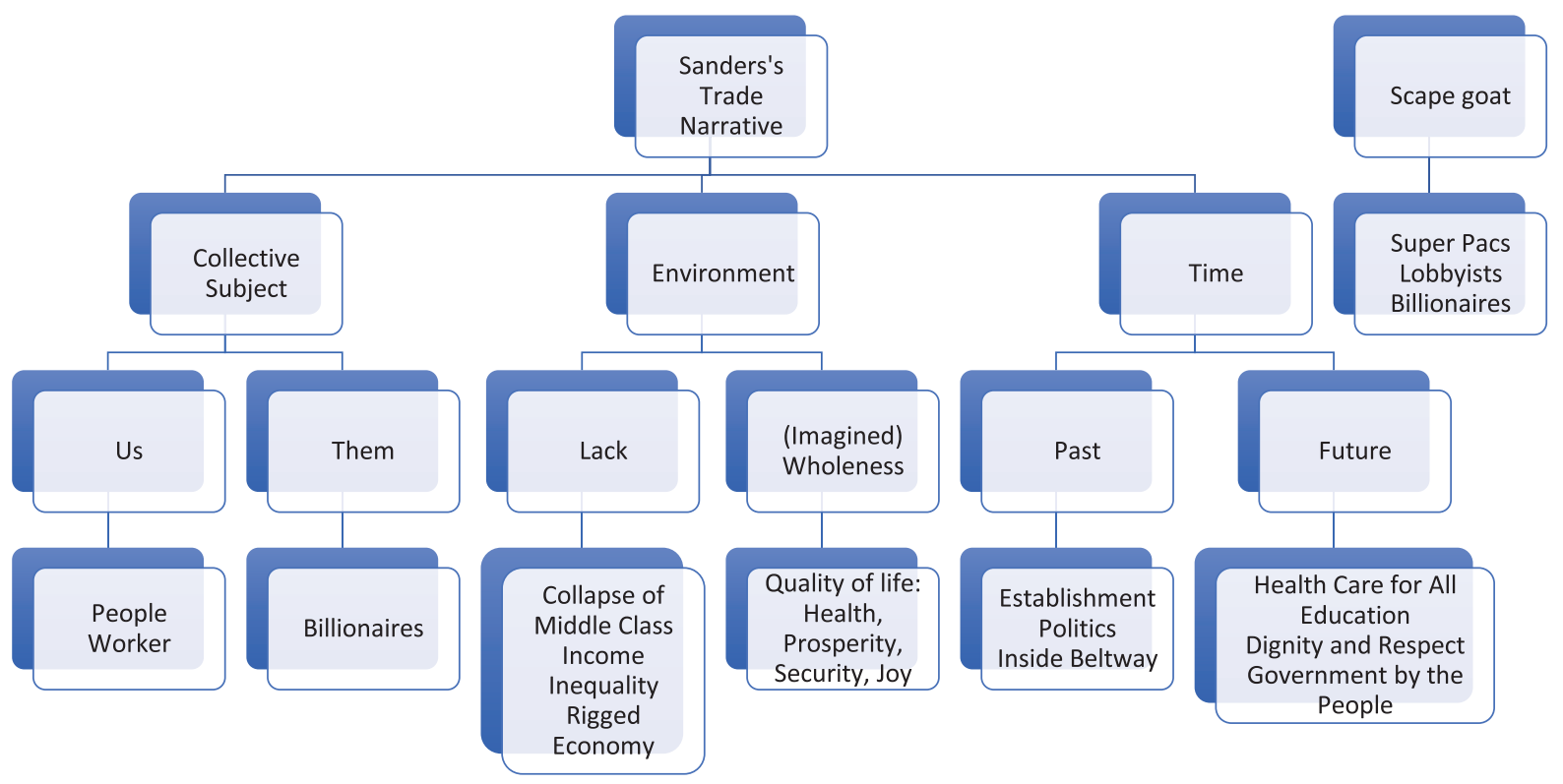

Figure 3. Bernie Sanders trade/TPP Narrative. 


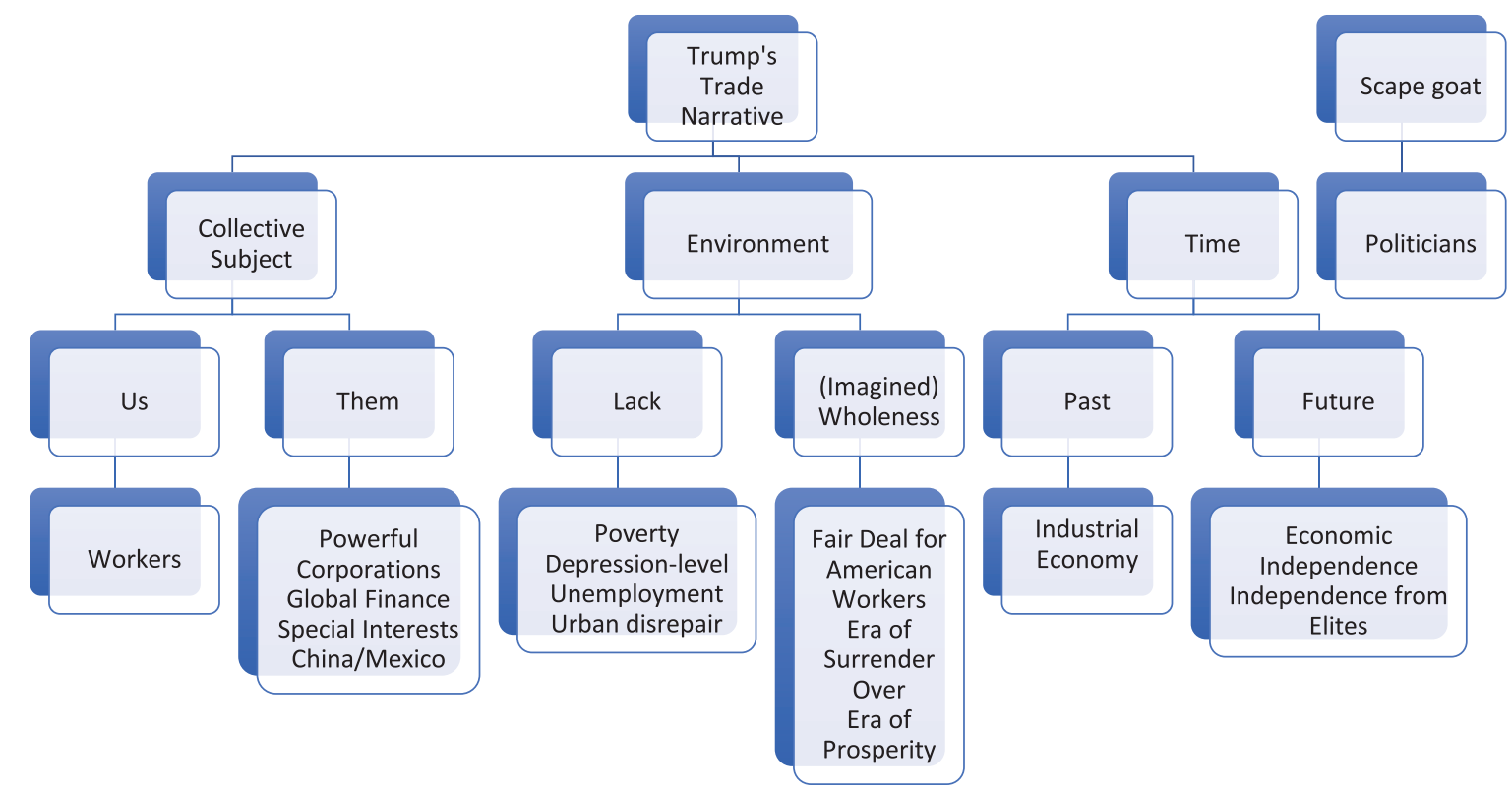

Figure 4. Donald Trump's trade narrative.

on his speech on trade at Nike:

Small businesses are the backbone of our economy....They employ millions of people, 98 percent of exporters are small businesses...they represent something essential about this country-the notion that if you've got a good idea and you're willing to work at it, you can turn that idea into a business, you can grow that business, and...you can give other people a chance to earn a living even as you do well. That's America's promise. And it's up to us to keep that promise alive. (Obama, 2015)

In this segment, President Obama connects the small business owner to an American identity that is often activated in trade campaigns. The classic promise of America or the American Dream is that everyone can be successful through hard work and ingenuity. But here, he evokes the American Dream storyline by placing small businesses as a subject who can help fulfill this American Dream promise.

In contrast, Sanders' and Trump's speeches establish the collective subjects in populist terms as 'workers' and the 'people'. Sanders characterizes 'the people' as change agents responsible for leading a revolution that will take back the government and the country from billionaires. He states:

Today, we stand here and say loudly and clearly that enough is enough. This great nation and its government belong to all of the people, and not to a handful of billionaires, their Super-PACs and their lobbyists. (Sanders, 2015)

Trump also constructs a collective subject of 'workers' in opposition to 'politicians' and 'financial elites'. Thus, at the outset of their speeches, Sanders and Trump similarly draw on populism to signal identification to the audience and also to position who is to blame for current, poor conditions of the American economy.

\subsubsection{Scapegoat and Transgression}

Also in the beginning of both speeches, Sanders and Trump blame at least one scapegoat for causing the current and past situation. Sanders clearly identifies who is to blame for disastrous trade policies and the economic hardship of middle-class Americans-the extremely greedy billionaire class and politicians who have supported free trade deals in the past. He states: "for decades, presidents from both parties have supported trade agreements which have cost us millions of decent paying jobs as corporate America shuts down plants here and moves to low-wage countries" (Sanders, 2015). Trump also immediately identifies a specific target of blame. He states:

Our workers' loyalty was repaid...with total betrayal. Our politicians have aggressively pursued a policy of globalization, moving our jobs, our wealth and our factories to Mexico and overseas. Globalization has made the financial elite, who donate to politicians, very, very wealthy. (Trump, 2016b)

In Trump's speech, he also raises China as a target of blame particularly in his direct references to the TPP. He states:

The Trans-Pacific Partnership is the greatest danger yet. The TPP, as it is known, would be the death blow for American manufacturing....It would further open our markets to aggressive currency 
cheaters-cheaters, that's what they are, cheaters. (Trump, 2016b)

By raising the issue of 'currency cheaters' in reference to the TPP, he associates trade disasters with one of his favorite scapegoats-China. By positioning the subject, China, in opposition to American identity, Trump constructs a well-known 'other' to the US self. He is able to contrast China to America-as a rule-breaker (cheater) and as an antithesis to American values. China is corrupt, America follows laws. China is a cheater, America plays on a level playing field.

President Obama also positions China as the distinct other in his story. Obama uses China as an opposite to the US but primarily by suggesting that if the US does not take a leadership role in Asia, China will-and in subsequent speeches he spells out that China is already working on a parallel trade agreement that mirrors the TPP but without many of the labor and environmental protections included. For example, he states:

Some folks think we should just withdraw and not even try to engage in trade with these countries. I disagree. We have to make sure America writes the rules of the global economy. And we should do it today, while our economy is in the position of global strength. Because if we don't write the rules for trade around the world-guess what-China will. (Obama, 2015)

While he implies that Chinese leadership in Asia and in trade is not a good thing, he avoids describing China's actions as a transgression against American workers (cheaters) and thus does not inspire audience desire for retribution against China in the way that Trump does. Indeed, China's rise is triggered by America's retreat and thus the blame falls on US actions, not China's. Thus, even Obama's attempt at blame fails to land squarely on an identifiable scapegoat.

On the other hand, Sanders and Trump are prolific in their use of emotional trigger words such as 'disaster', 'betrayal', 'greed', and urgency such as 'enough is enough'. By establishing a target of blame, they are able to direct the audience to a specific transgression of an 'other' responsible for stealing certainty and safety from the working class, and personally benefiting and even 'tricking' the working class out of its piece of the American pie. This creates an association of 'we-ness' from a much broader audience who can readily associate with a 'worker' or 'people' identity in contrast to a billionaire or corrupt politician. This approach was far more effective than Obama's construction of a 'small business owner' collective subject without a clear scapegoat or target of responsibility.

\subsection{Characterization of the Socio-Political Environment}

All narratives have a theme and in the TPP narratives, the theme relates to how the speakers characterize the socio-political environment relating to the economy. For,
Obama, his trade story characterizes the socio-political economic environment as robust, full of hope and thriving and thus closer to wholeness as opposed to lack. Indeed, President Obama references a past lack-the collapse of the US economy and the recession-that has been overcome by the hard work of small business entrepreneurs. He states:

[America's] promise was threatened for almost everybody just about seven years ago, when the economy nearly collapsed, and millions of Americans lost their jobs and their homes and their life savings. But thanks to the hard work of the American people and entrepreneurs...we're in a different place today. (Obama, 2015)

Here the credit for overcoming lack goes primarily to his constructed collective subject-entrepreneurs. While he vaguely references the American people, he immediately specifies he means entrepreneurs, the collective subject he emphasizes throughout the speech. He goes on:

So small businesses deserve a lot of credit. In fact, over the past several years, small businesses have created nearly two out of three new American jobs. And the question is, how do we build on success? We've got to be relentless in our efforts to support small businesses who are creating jobs and helping to grow the economy. (Obama, 2015)

This trade narrative positions a narrow and specific collective subject as pushing a thriving economy towards more American jobs and success in the future. As such, Obama's trade narrative fails to activate subject identification because his subject is narrow and one most Americans cannot relate to, and his environment characterization is more towards wholeness thus not sparking much desire on the part of the audience for change or fantasy.

In contrast, Sanders and Trump use their speeches to establish an assessment of the socio-political environment as eviscerated by bad past trade deals that have fundamentally transformed the American heartland and factory-working class. They continue to signal despair and lack, and then to inspire a fantasy of the future that can only come if either one of them is elected as the next president. For example, Sanders states that his campaign is going to send a message to the billionaire class that their "greed has got to end" (Sanders, 2015) and that under his leadership "trade policies will break that cycle of agreements which enrich at the expense of the working people of this country" (Sanders, 2015). According to Trump, globalization and the policies of the financial elite have left "millions of our workers with nothing but poverty and heartache", "jobs have vanished and our communities were plunged into Depression-level unemployment" (Trump, 2016b). Trump continues to establish lack and blame through a populist narrative, "our politicians took away from the people their means of mak- 
ing a living and supporting their families. Skilled craftsmen and tradespeople and factory workers have seen the jobs they love shipped thousands and thousands of miles away" and "towns are in a state of total disrepair". "Globalization has wiped out totally, totally, our middle class" (Trump, 2016b). The socio-economic environment is characterized as filled with despair, disrepair and economic devastation.

\subsection{Past and Future (Fantasy)}

Narratives are also distinguished by temporality or a sense of past and future. In Lacanian terms, temporality is a fantasy of what can come about in the future to bring about either wholeness and repair of a nightmare scenario of despair (Eberle, 2017). The past is also fantasized as it is selectively recalled to serve the overall purpose of the narrative theme. In Obama's trade narrative, he presents two futures of globalization-one where America is in charge and taking a leadership role (the beatific scenario of securing a complete identity), and one where the US takes a back seat to less-worthy leaders such as China (the nightmare scenario). For example, he states:

We can't stand on the beaches and stop the global economy at our shores. We've got to harness it on our terms. This century is built for us. It's about innovation. It's about dynamism and flexibility and entrepreneurship, and information and knowledge and science and research. That's us. (Obama, 2015)

This segment solidifies his trade/pro-TPP narrative-it positions an entrepreneurial collective subject that is able and willing to lead in new areas of economic growth.

For Sanders and Trump, the solution for past disastrous trade and economic policies comes with a fantasized economic future where the American dream can be restored to small factory towns in middle America. They both signal the American dream that has been forgotten but can be restored. Sanders states it as such:

I have seen the promise of America in my own life. My parents would have never dreamed that their son would be a US Senator, let alone run for president. But for too many of our fellow Americans, the dream of progress and opportunity is being denied by the grind of an economy that funnels all the wealth to the top. (Sanders, 2015)

For Trump, he also references a fantasized future of the American dream, he states: "you have a great future folks...I want you to imagine a much better life and a life where you can believe in the American dream again. Right now, you can't do that" (Trump, 2016b). In Sanders' and Trump's speeches, they reference a fantasized future that can restore a working-class American dream that returns factory jobs back to middle American by restoring 'America first' economic policies.
Sanders and Trump represent the past as both an example of bad choices by others (bad trade policies) and as an economic time before bad choices that can be reclaimed again. They seek to recapture something pure that was part of the American dream-whether it is governance by the people, or good, honest middleclass factory jobs that have been taken away by greedy elites. Trump's campaign slogan "Make America Great Again" suggests that Trump's platform is entirely focused on reclaiming what has been lost. Solomon (2013) suggests that an emphasis on lack (or what is missing) "drives desire for reclaiming that which has been lost" (p. 116) and that this conjuring of lack creates an effective and resonate discourse. In narrative terms, the type of subjects and the plot of overcoming a lack that is apparent in Sanders' and Trump's economic narratives explain, at least in part, what gave their trade stories more resonance.

Moreover, the candidates' narratives turned something rather unknown like the TPP, into an emotional story of betrayal, subversion, and conspiracy against the people. Sanders and Trump regularly deployed emotional trigger words and 'colorful' language to denounce free trade and the TPP. Indeed, in past and subsequent speeches and comments about US trade policy, Trump used the word 'rape' to describe bad trade deals. For example, he stated, "the Trans-Pacific Partnership is another disaster done and pushed by special interests who want to rape our country-just a continuing rape of our country" (Lima, 2016). Sanders' and especially Trump's use of emotional trigger words in association with trade helped elevate the issue's urgency and connect a policy issue that is often abstract with a visceral image of physical violation.

In contrast, Obama's trade narrative fails to appeal to three central features of resonance-a collective subject that inspires identification, a construction of an environment of lack that then sparks desire and affect in the audience for wholeness or at least a fantasy of wholeness, a sense of past that either inspires a harkening or something to overcome. It also lacks a fourth element that is a central part of the candidates' narrative, a transgression executed by a villain or a scapegoat. Moreover, Obama's speech was light on emotional trigger words and instead relied on a more typical narrative strategy that had worked in the past-constructing a positive American identity that is successful in the future and positioning trade as an extension of the American Dream and a crucial part of an inevitable globalization that can lead to success for the American middle class.

\section{Conclusions}

The article compares President Obama's and US presidential candidates Sanders' and Trump's TPP/trade narratives to provide an explanation for why populism resonated on both the political right and political left and upended President Obama's efforts to ratify the TPP during 
his final year. It finds that Sanders and Trump were more effective at constructing broader, more appealing collective subjects within an emotional, populist story of people versus elites to target free trade. In contrast, Obama's collective subjects, small business owners, evoked little desire for identification because small business owners and entrepreneurs were already successful in economic sectors such as technology, services and information. His narrative also failed to resonate because it focused too closely on American wholeness and success and painted a picture of a thriving American economy that failed to inspire a fantasy of change and was disassociated from the broader American experience.

Moreover, Sanders and Trump were more successful at constructing emotional narratives of lack, economic betrayal and despair. They painted a picture of a bygone America eviscerated by bad trade deals signed by financial elites who benefited at the expense of everyone else. They used emotional trigger words directed at easily accepted scapegoats to inspire audiences to connect their personal losses to abstract, complicated trade agreements, and promised economic revival and wholeness in the future. By evoking audience desire for reclaiming something lost, Sanders and Trump succeed in dominating the public debate on trade and sidelining the TPP, and ultimately prevented President Obama from bringing the TPP legislation to Congress for a vote. Once elected, President Trump 'unsigned' the TPP on his first working day in office fulfilling one of his most commonly stated campaign promises.

The article contributes to the rapidly growing literature on populism and emotions. While there is an explosion of explanations for why populism is gaining traction worldwide, few analyses thus far have closely examined the emotional language of elites regarding trade and economic policy for insights into how and why economic populism is proliferating. The article argues that trade policy must be constructed as something that audiences can relate to in order to gain enough support, and consequentially, trade stories present an opportunity for understanding the relationship between narratives, emotions and foreign policy.

\section{Acknowledgements}

The author would like to thank both reviewers and the editors of the thematic issue for their extremely helpful and insightful comments and suggestions on the article.

\section{Conflict of Interests}

The author declares no conflict of interests.

\section{References}

Arnold, L. (2016, July 26). Quicktake Q\&A: Why democrats are chanting 'No TPP' at convention. Bloomberg. Retrieved from https://www.bloomberg. com/news/articles/2016-07-26/quicktake-q-a-whydemocrats-are-chanting-no-tpp-at-convention

Bially-Mattern, J. (2011). A practice theory of emotion for International Relations. In E. Adler \& V. Pouliot (Eds), International practices (pp. 63-86). Cambridge: Cambridge University Press.

Bially-Mattern, J. (2014). On being convinced: An emotional epistemology of International Relations. International Theory, 6(3), 589-594.

Bleiker, R., \& Hutchison, E. (2014). Theorizing emotions in world politics. International Theory, 6(3), 491-514.

Clément, M., \& Sanger, E. (2018). Researching emotions in international relations. New York, NY: Palgrave.

Crawford, N. C. (2000). The passion of world politics: Propositions on emotion and emotional relationships. International Security, 24(4), 116-156.

Eberle, J. (2017). Narrative, desire, ontological security, transgression: Fantasy as a factor in international politics. Journal of International Relations and Development. https://doi.org/10.1057/s41268-017-0104-2

Eberle, J. (2018). Desire as geopolitics: Reading The Glass Room as central European fantasy. International Political Sociology, 12(2), 172-189. https://doi.org/ 10.1093/ips/oly002

Edelman, M. (1988). Constructing the political spectacle. Chicago, IL: University of Chicago Press.

Edkins, J. (2000). Whose hunger? Concepts of famine, practices of aid. Minneapolis, MN: University of Minnesota Press.

Ewick, P., \& Silbey, S. S. (1995). Subversive stories and hegemonic tales: Toward a sociology of narrative. Law \& Society Review, 29(2), 197-226.

Fierke, K. M. (2013). Political self-sacrifice: Agency, body and emotion in international relations. Cambridge: Cambridge University Press.

Glynos, J., Klimecki, R., \& Willmott, H. (2012). Cooling out the marks. Journal of Cultural Economy, 5(3), 297-320.

Hall, T. H. (2015). Emotional diplomacy: Official emotion on the international stage. Ithaca, NY: Cornell University Press.

Koschut, S. (2017a). The power of (emotion) words: On the importance of emotions for discourse analysis in IR. Journal of International Relations and Development. https://doi.org/10.1057/s41268-017-0086-0

Koschut, S. (2017b). Discourse and emotions in international relations. International Studies Review, 19(3), 481-508.

Lacan, J. (1981). The four fundamental concepts of psychoanalysis. New York, NY: W.W. Norton \& Company.

Lima, C. (2016, June 28). Trump calls trade deal 'a rape of our country'. Politico. Retrieved from https://www. politico.com/story/2016/06/donald-trump-trans-paci fic-partnership-224916

Miller, S. A. (2016, June 20). Obama touts TPP trade deal, bucks opposition from Clinton, Trump. The Washington Times. Retrieved from https://www.washington times.com/news/2016/jun/20/obama-touts-tpp-trade 
-deal-bucks-opposition-hillar

Minkenberg, M. (2000). Renewal of the radical right: Between modernity and anti-modernity. Government and Opposition, 35(2), 170-188.

Miskimmon, A., O’Loughlin, B. \& Roselle, L. (2013). Strategic Narratives. New York: Routledge.

Newport, F. (2017, June 21). Middle-class identification in US at pre-recession levels. Gallup. Retrieved from https://news.gallup.com/poll/212660/middleclass-identification-pre-recession-levels.aspx

Obama, B. (2015, May 8). Remarks on trade. The White House. President Barack Obama. Retrieved from https://obamawhitehouse.archives.gov/the-pressoffice/2015/05/08/remarks-president-trade

Oren, I., \& Solomon, T. (2015). WMD, WMD, WMD: Securitisation through ritualized incantation of ambiguous phrases. Review of International Studies, 41, 313-336.

Rico, G., Guinjoan, M., \& Anduiza, E. (2017). The emotional underpinnings of populism: How anger and fear affect populist attitudes. Swiss Political Science Review, 23(4), 444-461.

Salmela, M., \& von Scheve, C. (2017). Emotional roots of right-wing political populism. Social Science Information, 56(4), 567-595. https://doi.org/10.1177/ 0539018417734419

Sanders, B. (2015, May 26). Bernie's announcement. Bernie Sanders. Retrieved from https://bernie sanders.com/bernies-announcement

Sanders, B. (2016, April 29). Bad trade deals cost Indiana jobs, Sanders says. The American Presidency
Project. Retrieved from http://www.presidency.ucsb. edu/ws/index.php?pid=117585

Skonieczny, A. (2001). Constructing NAFTA: Myth, representation, and the discursive construction of US foreign policy. International Studies Quarterly, 45(3), 433-454.

Skonieczny, A. (2018). Trading with the enemy: Narrative, identity and US trade politics. Review of International Political Economy. https://doi.org/10.1080/ 09692290.2018 .1448879

Solomon, T. (2013). Resonances of neoconservatism. Cooperation and Conflict, 48(1), 100-121.

Solomon, T. (2014). The affective underpinnings of soft power. European Journal of International Relations, 20(3), 720-741.

Steele, B. J. (2010). Defacing power: The aesthetics of insecurity in global politics. Ann Arbor, MI: University of Michigan.

The Daily Show [TheDailyShow]. (2018, June 27). Move over 'lock her up' [Tweet]. Retrieved from https:// twitter.com/TheDailyShow/status/10120707619582 15680

Trump, D. J. (2016a, March 14). Disappearing middle class needs better deal on trade. USA Today. Retrieved from https://www.usatoday.com/story/ opinion/2016/03/14/donald-trump-tpp-trade-ameri can-manufacturing-jobs-workers-column/81728584

Trump, D. J. (2016b, June 28). Remarks on trade. Time. Retrieved from http://time.com/4386335/donaldtrump-trade-speech-transcript

\section{About the Author}

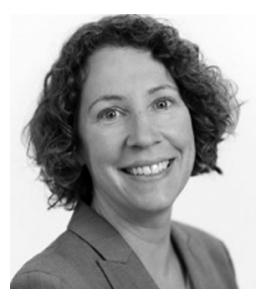

Amy Skonieczny is an Associate Professor at San Francisco State University in the International Relations Department. Her research interests include populism and foreign policy, narratives and US trade politics, and the study of national identity and foreign policy discourses. She has a forthcoming chapter (2019) titled "Populism and Trade: The 2016 US Presidential Election and the Death of the Trans-Pacific Partnership" in the volume Global Populisms edited by Dirk Nabers, Frank Stengel and Robert Pateman. Her most recent publications include an article in Review of International Political Economy titled "Trading with the Enemy: Narrative, Identity and US Trade Politics" (2018) and "Corporate Lobbying and Foreign Policy" (2017) in the Oxford Research Encyclopedia of Politics. Her complete list of publications can be found at her website. 